\title{
Review Study on the Supply Mechanism of Public Services under the Livelihood Finance
}

\author{
Huanhuan Hu \\ School of Management, Yulin University, China, 719000 \\ 277163838@qq.com
}

Keywords: Public Service, Livelihood Finance, Supply Mechanism

\begin{abstract}
The people's livelihood is the basic problem in China's economic and social development, and the people's livelihood finance is the main means to solve the problems of people's livelihood. In recent years, the Chinese government attaches great importance to the provision of public services, to allow all residents to feel the finance of people's livelihood "sunshine". From the situation in our country, the contradiction between supply and demand of public service in essence is the supply mechanism, to solve the contradiction between supply and demand of public service needs strong financial support, the more need for innovation mechanism. In the long run, has important theoretical value and practical significance of research on the mechanism of the supply of public services, which helps to promote the innovation of China's public finance and public policy theory, to promote public services in the reform, promoting the public service oriented government and the construction of socialist harmonious society.
\end{abstract}

\section{Introduction}

At present, China's public service shows the overall level is generally low, unbalanced development and low efficiency of the basic characteristics. According to the situation of our country, the contradiction between supply and demand of public service is essentially a problem of supply mechanism, to solve the contradiction between supply and demand of public service needs strong financial support, continuous innovation needs more mechanism. Therefore our government, to increase the supply of public service efforts, the key is to establish and perfect the supply mechanism of public services to cover all citizens, so that everyone can enjoy the people's livelihood finance under the "sunshine" service.

\section{Review of Foreign Studies}

Many foreign scholars from different angles on the government to provide public services, carried out a detailed study of public administration and governance of the public service ability, the use of public choice theory, system theory and game theory in a variety of ways, the connotation of public service scope, category a meticulous and detailed description, and put forward imagine the possibility of innovation and expansion of the supply mechanism analysis framework. The main representative figures and views:

Macro Level Research. From the macro level to study the reform of government governance mode and represents the task of how to improve the governance capacity and governance mode in the future works include: Peters and the "government, Osborn and Gaebler and co-author of" the reform of the government - enterprise spirit how to reform a handbook of public sector "and" Government Reform: strategies and Tools, and Badzere "the breakthrough of Bureaucracy: government management new vision", Deng Hart and thein Hart and co-author of "new public service: service rather than at the helm", and Drucker "new reality."

Institutional Economics Research. Institutional economic school representatives and their works are: Governance Way .Mr. Ostrom and co-author of "public affairs", institutional incentives and sustainable development "and" public service system construction and so on. they will use public resources in a specific area, and the maintenance of local public goods supply as the research 
object, study various social forces of diversified public affairs self governance system, highlighting the community public service system arrangements on their own self governance.

New Public Management Theory and New Public Service Theory. In the formation of government reform based on the theory of new public management and new public service theory, the most representative are: public management reform of public management and the British pariet Belgian Kerr co authored "Bao -- a comparative analysis of Murray's" New Zealand Political Economics public sector system, a famous American the theory of entrepreneurial government advocates Osborn and Ted Gaebler "reform of government -- how to reform the public sector entrepreneurship and on behalf of the United States Ostrom's" public affairs governance "and" public service classic service system construction. The new public service theory based on the theory of new public management review critically, in the United States came into being.

Practice in Many Countries. From the practice of many countries, the supply of public services must abide by the principle of fairness and efficiency. The efficiency of target priority or fair strategic goal priority, the supply mechanism of public services to the United States and France as the representative of the "minimum security and efficiency" in Britain and the Nordic countries as the representative of the "comprehensive fair" and in Singapore and Chile as the representative of the "efficiency oriented". However, there is a common point in these countries, according to the different levels of development to implement the different strategy focus. Overall, the research about the fairness of less and more research on efficiency.

The foreign research achievements are remarkable, which provides strong theoretical support for the reform of government governance mode and mechanism of public service reform in western countries. At the same time, it is also in China academic research field provides a useful reference and experience for reference, and a profound influence on the practice of the reform of our government in some areas, such as the industrialization of education reform, the reform of medical market, the utility supply mode.

\section{Review of Chinese Studies}

In 2005, the Chinese government clearly put forward to strive to achieve the service-oriented government transformation. Resulting in research on public service theory circles, from economics, finance, management science, sociology and other fields are widely studied and specific to the public service. Among them, the representative research results are: Li Junpeng "public service -theory and Practice on public service", China (Hainan) reform and Development Research Institute of" the construction of public service government" ,"transformation of government and social redistribution", "focusing on public service system Chinese", "Chinese public service system: Central and local". Chen Changsheng, "China the government's public service edited by Cai Yuezhou: a comprehensive assessment system change with area ", Wu Shenggong "To construct a service-oriented government", and Li Yongqing's "public service government".

China Academy of Social Sciences Professor Liu Guoguang believes that the implementation of people-oriented, improve the common people especially the low-income groups, social welfare, needs to increase financial investment in public service areas, gradually from the field of those who do not belong to the social public need to pull away, to achieve the economic development oriented finance into public service finance.

Chi Fulin pointed out that accounted for the proportion of fiscal expenditure in the social development and Chinese without significant increase in public welfare spending projects, especially in education, health, sports and social welfare accounted for a smaller proportion. In this regard, we should accelerate the construction of public financial system for the government to fulfill the public service and build the foundation of the system.

The State Council Development Research Center Weijianing believes that the overall size of China current local government debt burden all is quite large, as soon as possible to study how to solve the problem of local government debt. This should allow local governments to issue government bonds to the public, the implicit explicit debt, and then straighten out between the 
central and local governments and property rights the relationship between the powers, to avoid as far as possible below the county level departments at all levels of financial and debt crises.

Gao Shangquan believes that China's government at all levels of responsibility in the course of government in the construction of a harmonious society, plays a leading role instead. After defining the government overall responsibility for public service, but also actively promote the reform of the government responsibility and improve the combine.

Luo Yifei pointed out: follow the government in providing public service principles: first, we should adhere to the "advance and retreat". Whatever the market can do public service by the market to do; where the market is not done well, the government should take the initiative to assume responsibility; second, we should adhere to the "begin end if." the livelihood of the public service, such as the social security system, employment system, medical system can achieve the equalization of basic, basically is to exercise the function of the government.

Fang Gang believes that since the reform and opening up, in the process of public service supply, the existence of excessive market or excessive private tendency. It is closely related with our past historical environment. In the past, your government's supply of public services is an extreme swept all the process. And now easy to another extreme, fully market-oriented. Reflected is the problem of excessive private goods, public goods really need the government's organization, participation, even like health education quasi public goods, largely as needed to provide public goods, but should be combined with the market organization, jointly build organic mechanism.

$\mathrm{Yu}$ Ji said: the public service function of government should focus on solving the masses are most concerned about the issue. According to the fairness, justice, wide coverage, moderate level, the requirements of sustainable development, accelerate the construction of public services, to achieve universal access to basic public services, promote the education system, health system reform and improve the social security system of social assistance system. At the same time, the public service function of government should accept the supervision and restriction, the establishment of an effective public product and public service supply mechanism, strengthen the leading role of the government at the same time, to encourage and guide social forces to participate in a variety of ways to provide public services, strengthen the supervision of the behavior of the public service, improve the quality and level of public services.

Wang Yukai pointed out: the public service policy, scope, boundary and government capacity to conduct scientific assessment, develop suitable China stage improvement and development strategy of public service. To consider, to further clarify the responsibility of the government, especially in the field of basic public services, planning standards of public services, social welfare, social the protection of basic public services, strengthen public finance, strengthen the public service supply process and the result of regulation.

Rong Shengling said: in the public service more and more to the market at the same time, the transformation of government functions lag, "offside", "dislocation" and "Absence" phenomenon is serious, the imbalance of some dislocation of public enterprise reforms plus the aggravation of social injustice, development is not harmonious. In order to solve these problems. We should further improve the socialist public service mechanism.

He Jinghua pointed out that diversification is facing in the supply of public services is complex, dynamic environment, diversity of products. Multiple collaborative means the production and supply of public services is an open public participation mechanism in the public service. The collaborative multi supply system, intermediary between the role of government is to connect the public service of the producers and consumers of services. Around this problem, the government plays a role mainly in three ways, that is the supervision, coordination, production and so on.

In the thorough analysis of the domestic and international public service theories, the scholars have carried on the profound analysis to the present situation and the system question of our country public service operation. 


\section{Conclusion}

The research of this paper is on the basis of public service supply mechanism, the establishment of a social justice oriented balanced public service system, the creation of a market economy and public service supply mechanism combining the socialist road with Chinese characteristics. This is a hitherto unknown mechanism and innovation the theory of innovation, which is the forefront of public finance and welfare economics, theoretical study and practical promotion of public service supply mechanism in China, which has important value of the times.

Study on the supply mechanism of public services is helpful to promote the innovation of China's public finance and public policy theory, promoting mechanism of supply of public service reform in our country, and promote the transformation of public service oriented government and the construction of socialist harmonious society theory and vision. The experience of the relevant research mainly focuses on the following aspects:

(1) the system design introduced the private supply of public goods in western countries, such as commercialization, marketization and decentralization mode; starting from the perspective of public finance, with the financial expenditure, the government level and the structure of property rights and other objective conditions, try to define the government and market, government powers of City public relations; market operation the mechanism and reform.

(2) from the government and public ethics point of view, the scope of the government's public service functions, status and value basis; especially the system reform and the angle of the system construction, the logic of reform of social problems and government relationship beneficial to the people's livelihood.

(3) mainly conducts the research from the social intermediary organizations and the community level, such as the process of transformation of government management in social intermediary organizations, the construction of rural production of social service system, community public service city supply mode.

In general, the domestic research on public service is still in its infancy, there is no systematic theoretical framework, especially for the public service supply mechanism for the lack of detailed and specific summarization and demonstration. More research point of view is from the way of management research, extension management research in the path of government behavior in the field of the research the starting point, hypothesis and demonstration system are printed with traces of profound study economics, weak public economic and fiscal policy theory. Limits the scope of research in the public service structure, the static description of the functions and powers, to stay in the public service structure, the static description of the functions and powers, failed to cooperate on under different constraint conditions the dynamic mechanism and mode choice departments in-depth analysis. Research on the relationship between are often not balanced theory and technology policy, the lack of empirical facts to observe And the mechanism and way of refining, too much emphasis on theoretical deduction, and the lack of feasibility considerations, the theoretical results of the policy guidance is not strong, pending further study and discussion.

\section{References}

[1].Wang Yuling. Explore the problem of how to expand private investment in financial crisis, [J]. Chinese collective economy, 2009 (16)

[2].Zhang Hanya. The advice about guide non-governmental investment [J].China investment, 2014 (5)

[3].Tang Min. A pressing matter of the moment to ensure growth is to stimulate private investment [J]. China foreign, 2009, (03)

[4].Chao Xiaojing, Ren Baoping. Economic transition, private investment and government investment to growth -- Empirical analysis of Chinese investment driven growth of economic high speed [J]. Economic science, 2008, (02)

[5].Huang Minyou. The synergistic action of government investment and private investment in recovering economy [D]. Guangxi Normal University, 2014 